\title{
Patologia de peixes da Amazônia Brasileira, 1. Aspectos gerais
}

\author{
Vernon E. Thatcher $\left(^{(*)}\right.$
}

\begin{abstract}
Resumo
Alguns aspectos gerais da patologia de peixes amazônicos são apresentados, e os princípios que governam as doenças em peixes mencionados, tais como: a) peixes amazônicos estão pouco expostos à poluiçấo industrial, mas podem ocorrer mortalidades grandes provocadas pela combinação de quedas na temperatura ambiental e a decomposiçāo de matéria vegetal; b) os peixes que morrem primeiro são aqueles que têm infecçōes nas brânquias; c) deve esperar-se pouca patogenia óbvia nos peixes recentemente capturados porque um peixe doente é rapidamente eliminado pelos predadores; e d) a patogenia pode ser estudada por meio de um levantamento de parasitas e outros fatores nos peixes na natureza, e depois, por observaçōes dos efeitos dos mesmos em cativeiro. Foram apresentados os mecanismos de defesa utilizados pelos peixes amazônicos contra: 1) corpos estranhos; 2) fungos; 3) mixoesporideos; 4) monogéneos; 5) trematódeos digenéticos; 6) cestodários; 7) cestóides; 8) acantocéfalos; 9) nematódeos; 10) crustáceos e 11) pentastomídeos, e exemplos destes são citados do Amazonas. São mencionadas a presença da doença das manchas pretas e três variedades da doença das manchas amarelas na regiăo. O nematódeo, Goezia spinulosa, já reconhecido como um perigo para a piscicultura, também é citado na Amazônia. O trematódeo parasita do olho, Diplostomum, o qual pode ser patogênico e fatal para o peixe e para o homem, foi encontrado em dois hospedairos. Um caso de adipose dentro do coração é citado de um pirarucu, Arapaima gigas. Já que o peixe tinha sido mantido num aquário pequeno por mais de um ano, é possível que uma insuficiência de exercício causou esta anomalia.
\end{abstract}

\section{INTRODUÇĂO}

A patologia dos peixes torna-se cada vez mais importante $\mathrm{com}$ o crescente interesse mundial na piscicultura. Poucos trabalhos gerais têm sido publicados sobre este tema e a maioria deles é referente às doenças de peixes da América do Norte ou da Europa. Entre eles. destaca-se o livro de Reichenbach-Klinke (1973) baseado principalmente na patogenia encontrada nos peixes europeus.
Sobre a patologia em peixes amazônicos, não existe nenhum estudo geral. No entanto, já foram publicados vários trabalhos sistemáticcs sobre os parasitas em peixes da região. Alguns parasitas grandes e conspícuos foram descritos no século passado, especialmente na monografia de Diesing (1850). Recentemente, levantamentos taxionômicos dos parasitas de peixes estão sendo feitos no Instituto Nacional de Pesquisas da Amazônia, Manaus, Amazonas.

O presente trabalho pretende ser o primeiro de uma série sobre a patologia nos peixes amazônicos, bem como uma tentativa de relacionar os parasitas e outros fatores como as causas daquela. Espera-se que esta série sirva como uma base para a diagnose, prevenção e tratamento das doenças de peixes neotropicais. especialmente para as espécies mais utilizáveis na piscicultura.

Os fatores causadores de patogenia e morte em peixes podem ser agrupados em várias categorias gerais. Entre eles, destacam-se a poluição industrial, a putrefação da matéria orgânica na água e a invasão do peixe pelos agentes biológicas (viroses, bactérias, fungos, vermes e outros).

Embora a poluição industrial seja a causa principal dos grandes morticínios de peixes no sul do Brasil, não é ainda um fator importante na maior parte da Amazônia. As mortandades de peixes observadas com freqüência na Amazônia se devem a uma combinação de causas Assim, as bruscas quedas na temperatura do ar podem esfriar a camada superior da água, fazendo com que ela se aprofunde numa movimentação vertical. Como conseqüência da subida das águas mais profundas, o nível de oxigênio fica reduzido. Estas águas têm pouco oxigênio porque matéria orgânica vai se acumulando no leito do rio, especialmente nas águas

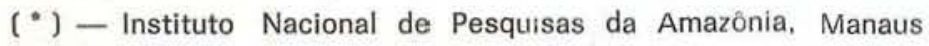


lênticas, e a putrefação deste material utiliza o oxigênio disponível. Qualquer baixa do nível de oxigênio dissolvido vai atingir primeiro aqueles peixes que têm uma doença no sistema respiratório, em especial as brânquias. Assim, um agente biológico que ataca as brânquias, ou simplesmente mora lá, pode ser considerado potencialmente patogênico, ainda na ausência de uma patogenia óbvia.

Quanto à patogenia induzida pelos parasitas, apresentamos aqui os seguintes princípios básicos :

1) $O$ ambiente aquático facilita o acesso e a penetração dos agentes patogênicos e, por isto, os peixes são os vertebrados mais parasitados;

2) A concentração de peixes de uma espécie, a que é usada na piscicultura intensiva, facilita ainda mais a transmissão de parasitas e o aparecimento de doenças:

3) Ambientes lênticos facilitam a transmissão de doenças mais que as ambientes lóticos;

4) Os peixes transmitem parasitas a outros animais (e ao ser humano) e servem de hospedeiros intermediários para muitas espécies de parasitas;

5) $\mathrm{Na}$ natureza um peixe que está doente ou debilitado não vive por muito tempo porque é rapidamente devorado pelos predadores (peixes, aves e mamíferos). Por isto, não se espera encontrar muitas indicações patogênicas nos peixes capturados:

6) Outros peixes doentes morrem e extraviam-se durante a captura e transporte ao laboratório, limitando ainda mais a possibilidade de encontrar manifestações de patogenia. Só os peixes mais fortes são vistos;

7) $\mathrm{Na}$ Amazônia, quase todos os peixes estão infectados com parasitas (geralmente com mais de uma espécie), mas isto não deve ser considerado como um estado "normal" no sentido de ser insignificante para a piscicultura;
8) Os peixes trazidos do ambiente natural vão estar infectados com vários parasitas, o que poderia invalidar qualquer experimento sobre o crescimento;

9) A grande maioria dos peixes que morrem em cativeiro sofrem uma insuficiência de oxigênio nas células. Esta pode ser causada por um baixo nível de oxigênio na água, ou por falhas no sistema respiratório dos peixes. Neste úlimo caso, a causa mais provável seria parasitas infestando as brânquias;

10) A grande maioria dos peixes mortos na natureza (na ausência de produtos tóxicos) também são vítimas de asfixia, e os primeiros a morrer sempre são aqueles que têm as maiores infecções nas brânquias;

11) A maioria dos peixes mortos não mostram patogenia nenhuma, além de uma secreção excessiva de muco nas brânquias;

12) Qualquer parasita deve ser considerado como potencialmente patogênico, ainda na ausência de uma patogenia óbvia;

13) Uma infecção maciça com uma espécie de parasita tende a produzir mais efeito negativo que apresença de poucos indivíduos da mesma espécie;

14) A presença de duas, ou mais, espécies de parasitas num peixe pode ser mais prejudicial que qualquer uma das espécies sozinha;

15] Um peixe pode ser parcialmente envenenado pela absorção de produtos químicos de excreção dos parasitas sem mostrar conseqüentes modificações nos tecidos, além de uma taxa reduzida de crescimento;

16) A patogenia é observada com mais freqüência nos peixes em postos de piscicultura do que na natureza, principalmente pela eliminação ou limitação do fator de predação. 
Assim, a patologia em peixes de qualquer região deve começar com um levantamento dos parasitas e outros agentes de doenças e continuar com observações sobre os efeitos dos mesmos nos peixes em cativeiro.

\section{MÉTOdos E MATERIAIS}

Os peixes usados foram capturados pelos funcionários do Instituto Nacional de Pesquisas da Amazônia, próximo de Manaus, Amazonas, Brasil. Os métodos de necropsiar os peixes e preparar os parasitas foram os citados anteriormente (Thatcher, 1978). Tecidos de peixes mostrando patogenia foram fixádos em formol a $10 \%$, emblocados em parafina e corados com hematoxilina - eosina. Pedaços achatados do intestino e mesentério foram montados inteiros com os mesmos métodos usados para trematódeos.

\section{Resultados}

\section{CORFOS ESTRANHOS NOS TECIDOS}

Foi bastante comum encontrar espinhos de plantas, ou de artrópodos, penetrados nas paredes do trato digestivo e nos mesentérios dos peixes amazônicos. Ocasionalmente, foram visto espinhos alcançando o fígado, a bexiga natatório e outros órgãos. Aparentemente, estes objetos não causam muita inconveniência ao peixe. A penetração inicial vai acompanhada por uma infiltraçäo de células que vão formando uma cápsula tibrosa, envolvendo o objeto. A Foto 14 mostra um espinho na parede do intestino do acará-açu, Astronotus ocellatus (Agassiz), que está parcialmente encapsulado.

Nãc foi possível determinar ainda o tempo necessário para a encapsulação de espinhos nos peixes neotropicais, mas provavelmente seria um período de poucos dias. Howell (1973) fez um experimento, no qual implantou contas de vidro nas cavidades peritoneais de um peixe australiano e, depois de três dias, as encontrou completamente encapsuladas. O mesmo autor notou que a mesma defesa é usada pelos peixes contra invasores vivos, como trematódeos, mas estes são capazes de resistir ao processo umas três semanas.

\section{MICROORGANISMOS (viroses e bactérias)}

Não foi possivel incluir estes microorganismos no presente estudo, mas infecções desse tipo sem dúvida ocorrem nos peixes amazônicos. Pouco se sabe sobre virose nos peixes. Sob o ponto de vista da piscicultura, infecções bacterianas geralmente representam invasões secundárias que podem ser tratadas com antibióticos.

\section{FUNGOS}

igual às bactérias, os fungos freqüentemente aparecem nos peixes como infecções secundárias e, assim, podem ser apenas um sintoma de outros problemas. O fungo conhecido mundialmente como um invasor dos tecidos cutâneos e subcutâneos é do gênero Saprolegnia. Este fungo já foi citado em peixes no sul do Brasil por Stempniewski (1970), o qual considerou ser este fungo um invasor secundário que só consegue infectar o peixe já doente ou ferido. É uma infecção fácil de reconhecer à olho nu, já que apresenta tufos de hifas brancas, parecidas com algodão, proje. tando-se um a três centímetros acima da pele do peixe. No presente estudo, foi visto um pirarucu grande, Arapaima gigas (Cuvier), aparentemente morto de uma infecção maciça de Saprolegnia sp. O peixe tinha sido mantido num aquário por mais de um ano, antes de morrer. Ele mostrou os tufos típicos por todas as partes do corpo, nas nadadeiras, dentro da boca e nas brânquias. Onde os tufos das hifas se juntavam com a pele, apresentavam-se áreas de ulceração de tamanho variável. Dentro das hifas do fungo, foi observado um verdadeiro microcosmo de seres vivos. Além das bactérias, havia muitos animais invertebrados considerados como de vida livre, especialmente saprófagos. Entre os animais aquáticos mais comuns figuravam protozoários, cilióforos, nematódeos e anelídeos. A causa imediata da morte deste peixe provavelmente foi uma insuficiência respiratória induzida pela saprolegnose das brânquias, mas podemos supor que a causa verdadeira da infecção teria sido o estado nutricional do peixe, ou a qualidade inadequada da água. 
Foi visto também um caso de um fungo, ainda não identificado, atacando um peixe amazônico na natureza. O peixe era um tambaqui jovem, Colossoma macropomum (Cuvier), de aproximadamente $20 \mathrm{~cm}$ de comprimento, o qual mostrava uma fileira de nódulos pálidos de cerca de três centímetros de comprimento no lado dorsal. Os nódulos eram arredondados, ligeiramente achatados e mediam entre 1 até $5 \mathrm{~mm}$ de diâmetro (Foto 9). Cortes destas áreas revelaram intensas infiltrações de linfócitos e fagócitos em torno das hifas e zoosporângios do fungo (Foto 15), indicando ser esta uma invasão do fungo devida a uma ferida e que o peixe ia se recuperando.

\section{FILO PROTOZOA}

A maioria dos protozoários patogênicos vistos em peixes amazônicos pertenciam à Ordem Myxosporida e à Classe Cnidosporida . Estes parasitas formam cistos brancos nos tecidos dos peixes que são freqüentemente visíveis a olho nu em virtude de ter um tamanho entre um até vários milímetros de diâmetro. Dentro dos cistos ocorrem os esporos vegetativos do parasita, os quais são relativamente fáceis de identificar até o gênero.

\section{Henneguya sp.}

O gênero Henneguya se distingue pela presença de um a três prolongações posteriores na casca do esporo. E um parasita bastante comum nos tecidos de peixes e é reconhecido como patogênico. Foram citadas 17 espécies do gênero na América do Norte, 7 das quais infectam peixes da Ordem Siluriformes, segundo Hoffman (1974). Uma destas espécies se localiza dentro das lamelas das brânquias e foi citada como a causa de perdas significantes nos cultivos de bagres na parte Sul dos Estados Unidos (McCraren et al., 1975) .

Henneguya, aparentemente representando várias espécies, foi encontrada nas brânquias dos seguintes peixes amazônicos no presente estudo: tambaqui; matrinchã, Brycon melanopterus (Cope); surubim, Pseudoplatystoma fasciatus (L.); caparari, P. tigrinus (Schomburgk); e pescada, Plagioscion squamosissimus (He- ckel). Dentro da lamela da brânquia o cisto interfere com a circulação do sangue e provoca a hipoplasia dos filamentos respiratórios (Foto 10 ) .

\section{Myxobolus sp.}

Os cistos deste gênero foram vistos em vários peixes amazônicos. Estes cistos são parecidos com os de Henneguya e produzem efeitos semelhantes. Os esporos são ovalados, ou arredondados, e carecem das prolongações da casca que caracterizam os de Henneguya. A Foto 11 mostra uma corte de um cisto de Myxobolus no fígado de um tambaqui, cheio de esporos. Um cisto destes no fígado, baço ou outro órgão, enquanto vai crescendo, causa a absorção das células do órgão reduzindo a capacidade funcional do mesmo. A Foto 19 mostra alguns esporos iiberados de um cisto que foi localizado dentro de um raio da nadadeira dorsal de um matrinchã. Pode ver-se as cápsulas polares dos esporos. Os cistos eram pequenos e numerosos, e infectaram quase todos os raios de todas as nadadeiras deste peixe.

\section{FILO PLATYHELMINTHES}

\section{CLASSE MONOGENOIDEA}

Os monogênios são parasitas das brânquias e pele de peixes e outros animais aquáticos. A patogenia produzida por estes vermes é geralmente limitada a pequenas irritações e uma secreção excessiva de muco, mas infecções maciças são capazes de causar a morte de peixes por asfixia. É conhecido mundialmente que estes vermes constituem um dos problemas mais importantes na prática de piscicultura.

Os Monogenoidea são chamados assim por ter um ciclo de vida direto que não precisa de hospedeiros intermediários. Têm um grau de especificidade surpreendente, sendo cada espécie geralmente limitada a uma espécie de peixe ou às espécies do mesmo gênero. Um só hospedeiro pode ter até oito espécies de Monogenoidea de uma vez (Price, 1967) e existe evidência no sentido de que cada espécie tem uma preferência para certas lamelas ou partes das brânquias (Suydam, 1971) . 


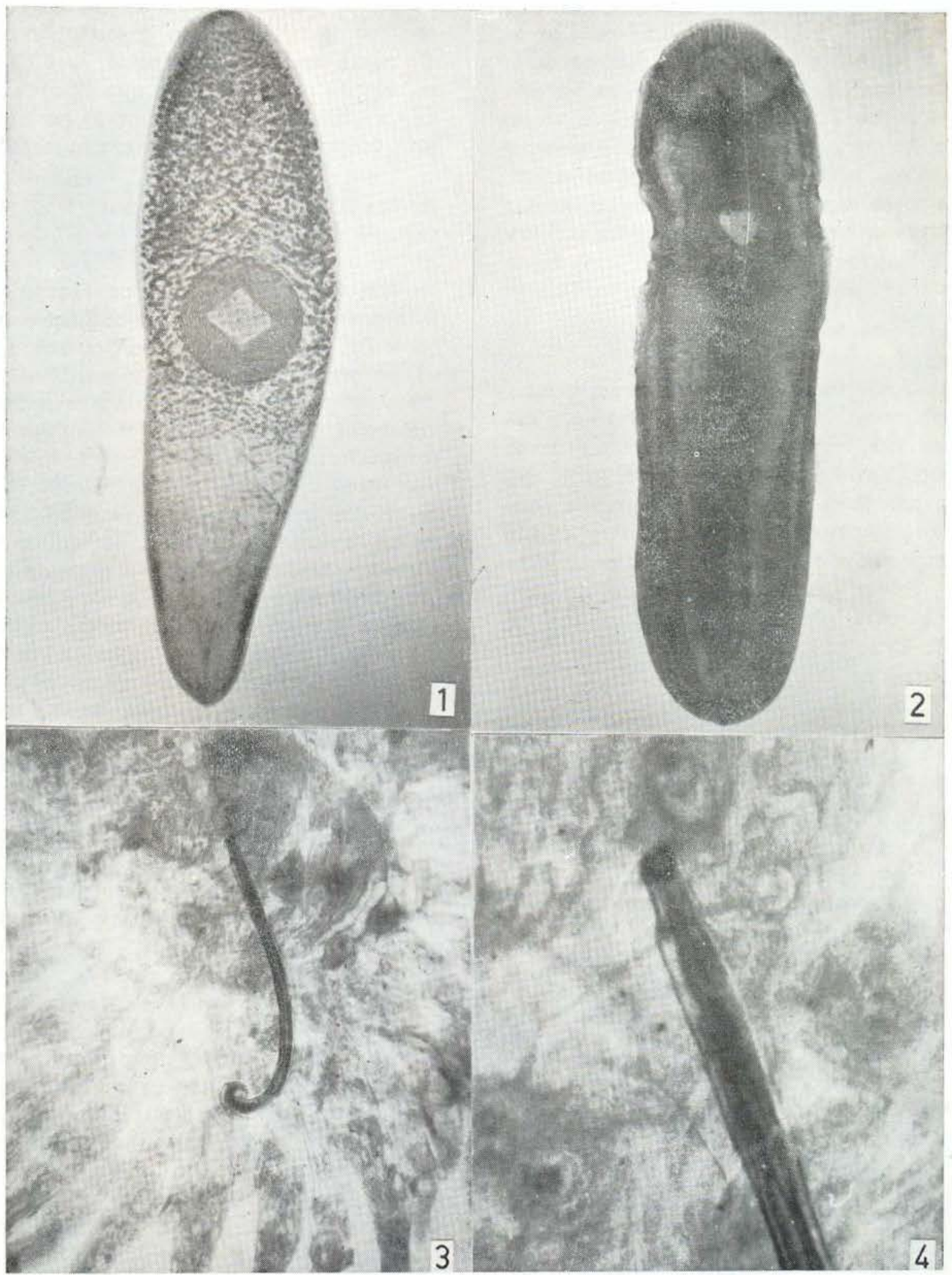

1 - Metacercária de Odhneriotrema sp. do testículo do bodó (x 20); 2 - Metacercária de Clinostomum marginatum da pele do tucunaré ( $x$ 30); 3 - Nematódeo (Spirocamallanus sp.) e cestóides (plerocercóides de Proteocephalidae) no intestino e cecos pilóricos do matrinchã $(x$ 10); 4 - Igual ao número 3 , mostrando infiltraçōes de células ao redor dos plerocercóides (x 50). 
Os monogêneos têm sido pouco estudados na América do Sul, especialmente aqueles de água doce. Até o ano 1964, só duas espécies de água doce foram conhecidas em todo o continente. Price (1967) citou um total de 17 espécies de monogênios de água doce sul-americanos até aquele ano. Mais recentemente, várias novas espécies e gêneros foram citados de peixes de água doce na Colômbia por Kritsky \& Thatcher $(1974,1976,1977)$ e no Brasil (Amazonas) por Kritsky, et al. (1979a, 1979b).

No presente estudo, monogêneos foram encontrados nas brânquias de todos os peixes examinados. Infecções em peixes recentemente capturados variam de alguns poucos até mais de 3000 indivíduos. Além de um excesso de muco nas brânquias mais infectadas, nenhuma patogenia foi notada. Nos peixes mantidos em aquários algum tempo, a incidência foi alta também e a intensidade foi geralmente maior. Foram vistos casos fatais em um tanbaqui e uma pirapitinga, Colossoma bidens (Spix). Estes peixes morreram asfixiados por infecções com Anacanthorus sp., Dactylogyridae, (Foto 6 ) . em números estimados em mais de 300.000 indivíduos por peixe.

\section{CLASSE TREMATODA}

\section{SUBCLASSE DIGENEA}

Os trematódeos digenéticos constituem um grupo grande de vermes que parasitam todas as Classes de vertebrados e que podem ser enccntrados em qualquer órgão ou tecido. A melhor referência taxionômica brasileira aos adultos deste grupo é o trabalho de Travassos et al. (1969). Estes trematódeos têm um ciclo de vida complexo com estágios larvais em caramujos. O peixe pode estar infectado com trematódeos adultos (sendo neste caso o hospedeiro definitivo do parasita) ou pode servir de hospedeiro intermediário, portando, então, o estágio larval chamado de metacercária. De uma maneira geral, podemos dizer que os estágios larvais e alguns adultos, que invadem os tecidos, são mais patogênicos que os adultos que vivem nas cavidades naturais do corpo (intestino etc.).
Na prática da piscicultura podemos pensar que um trematódeo tem importância se: 1) ele causa uma doença no peixe, ou é capaz de matá-lo; 2) é tão conspícuo que dificulta a venda do peixe ao consumidor ou 3) pode causar uma doença ou a morte do ser humano.

DOENÇA DAS MANChaS AMARELAS ("Yellow-spot Disease")

Nos Estados Unidos e na Europa ocorre uma doença de peixes bem conhecida com o nome de "yellow-spot disease", ou seja a doença das manchas amarelas. As manchas amarelas, características desta doença, representam metacercárias da Família Clinostomidae, sendo a espécie mais comum no mundo inteiro $\mathrm{Cli}$ nostomum marginatum (Rudolphi, 1819); (Foto 2). Estas metacercárias se encontram em várias espécies de peixes e os adultos vivem na boca e esôfago de garças e outras aves piscívoras. Esta mesma espécie de parasita toi vista no Amazonas nos seguintes ciclídeos: tucunaré (Cichla ocellaris Schneider) e Crenicichla. No tucunaré, só alguns poucos cistos foram encontrados nas brânquias, mas a Crenicichla apresentou cistos nas brânquias e numerosas manchas amarelas na pele e dentro das nadadeiras.

Mais uma forma de manchas amarelas foi encontrada no bodó (Pterygoplichthys sp.). Trata-se do gênero Odhneriotrema, também da Familia Clinostomidae. As metacercárias são grandes, aproximadamente $6-8 \mathrm{~mm}$. de comprimento, e formam cistos nas gônadas dos peixes. Neste habitat, os cistos provocam uma hipoplasia ou reabsorção dos tecidos e reduzem, assim, a capacidade reprodutora do peixe. Esta metacercária (Foto 1.. provavelmente representa a O. microcephala (Travassos, 1922). descrito o adulto do jacaré, sendo esta a única espécie conhecida no Brasil.

\section{MANCHAS AMARELAS DO OPÉRCULO DA PESCADA}

Todas as pescadas examinadas no presente estudo apresentaram manchas amarelas, de tamanho e forma variável, nos tecidos subcutâneos do lado interior dos opérculos. Dentro destas áreas foram encontrados trematódeos 


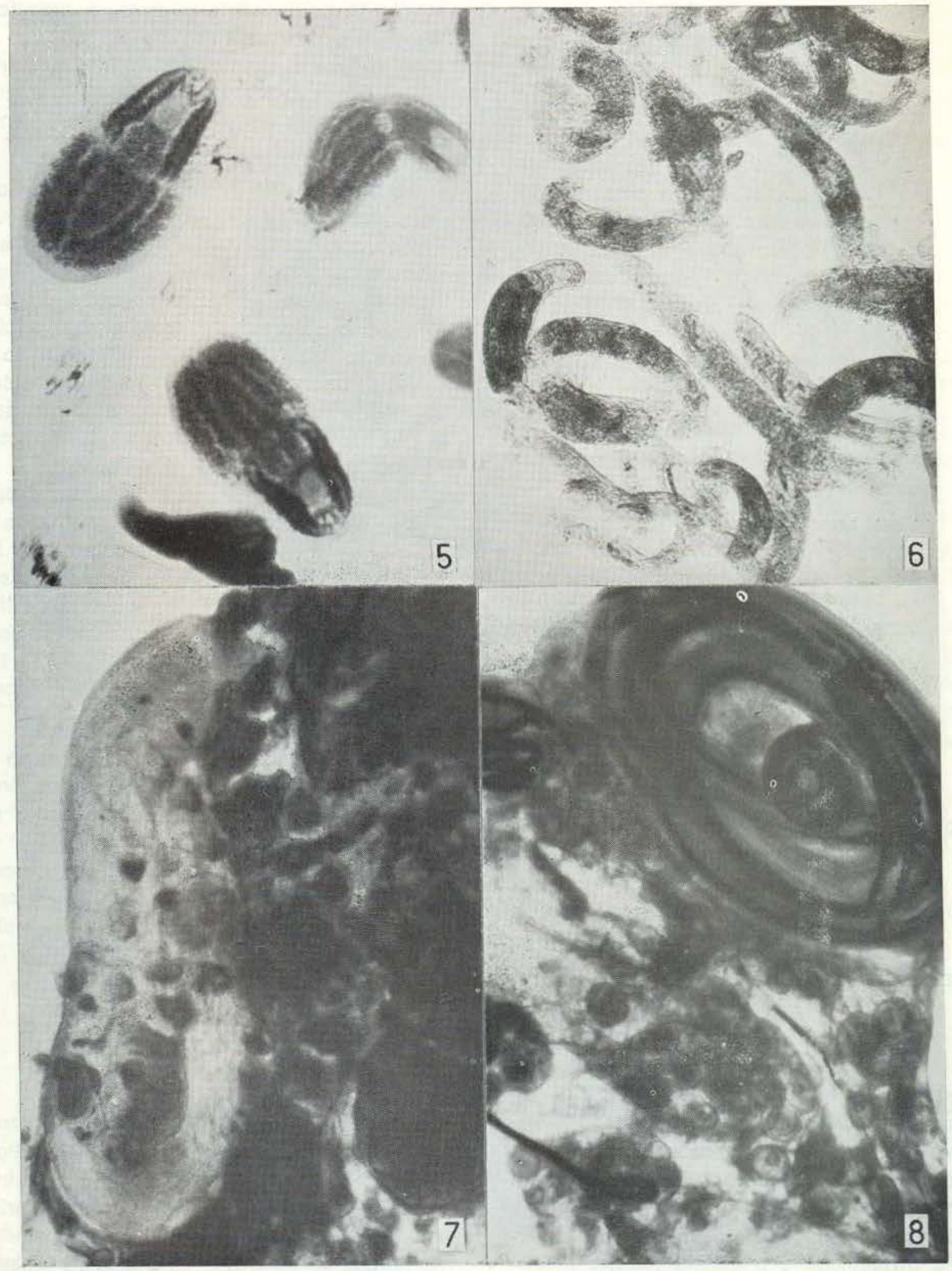

5 - Mesocercárias de Diplostomum sp. do bodó ( $x$ 80); 6 - Monogênios das brânquias do tambaqui $(x$ 65); 7 Larvas embriōes e ninfa de Pentastomida encistados no mesentério do surubim $(x 40) ; 8$ - Larvas de nematódeos e embriōes de Pentastomida encistados no mesentério do surubim ( $x$ 40). 
da Familia Didymozoidae. Este verme resul. tou ser um gênero $\epsilon$ espécie nova, e foi dado o nome Brasicystis bennetti por Thatcher (1979b), (Foto 17) .

Como as manchas são grandes e numerosas, podem dificultar a venda dos peixes ao consumidor exigente. Parecem não incomodar muito a vida dos peixes, mas a presença dos helmintos provoca a formação de redes sangüíneas que servem para prover nutrientes aos parasitas. Este fato já foi notado em outras espécies da Família por Yamaguti (1971). Alguns cistos também formam-se nas brânquias, o que pode interferir na respiração dos peixes.

\section{DOENÇA DAS MANCHAS PRETAS ("Black-spot Disease)}

Também conhecida mundialmente, é uma infecção chamada "black-spot disease" (doença das manchas pretas). Esta condição é causada pelas metacercárias de várias Famílias de trematódeos digenéticos. A cor preta se deve à inclusão na parede do cisto de grânulos de pigmentação por parte do peixe. Esta reação é estimulada pela presença ou a penetração da metacercária de uma maneira ainda desconhe. cida. Manchas pretas contendo metacercárias vivas foram vistas nas nadadeiras do matrinchä (Foto 20). Os trematódeos parecem representar a Família Acanthostomidae, os membros da qual geralmente amadurecem em répteis (crocodilianos) ou em peixes piscívoros.

\section{o tRematódeo do olHo ("Eye-fluke Disease")}

Também com distribuição mundial, é uma infecção de peixes chamada "eye-fluke disease" (doença de trematódeos nos olhos). O pei$x e$ infectado é fácil de diagnosticar, sendo vistas metacerárias (ou mesocercárias) de um trematódeo livre no olho. Estas larvas têm forma característica, e são visíveis à olho nu (Fotc 5). As metacerárias pertencem à superfamília Strigeoidea e o gênero melhor conhecido é Diplostomum. Travassos et al. (1969) citam 32 gêneros com 64 espécies deste grupo já conhecidos no Brasil. Todos eles presumívelmente utilizam peixes ou anfíbios como hos- pedeiros intermediários, e amadurecem no trato digestivo de répteis, aves e mamíferos. Entre as várias espécies de strigeóides, algumas encistam no hospedeiro intermediário e outras ficam livres nos tecidos. É este último grupo de espécies que causa o maior dano ao animal infectado.

As mesmas espécies que infectam os olhos de peixes podem ser encontrados em outros órgãos, mas tendem a ser mais numerosos nos olhos e nos lobos ópticos do cérebro. Nestes habitats podem causar a cegueira do peixe, facilitando a sua captura pelo animal piscívoro e, assim, assegurando a completação do seu ciclo. O interesse neste grupo de trematódeos foi estimulado nos últimos anos com o descobrimento de que as larvas podem infectar o homem e, quando presentes em número suficiente, causar-lhe a morte. Freeman et al. (1976) citaram o caso de um canadense que foi morto em apenas 9 dias depois de ter ingerido larvas do gênero Alaria. Segundo Ashton et al. (1969), duas citações existem na literature sobre infecções do olho humano com o gênero Diplostomum. Travassos et al. (1969) citam 3 espécies de Alaria e 2 de Diplostomum para o Brasil.

No presente estudo, metacercárias de Strigeoidea foram observadas em vários órgãos dos seguintes peixes: bodó; acará-açu; cuiúcuiú, Oxydoras niger (Valenciennes); e Geophagus surinamensis (Bloch). Metacercárias identificadas como Diplostomum foram encontradas nos olhos do matrinchã e no ciclídeo Crenicichla sp.

\section{CLASSE COTYLODA (= Cestodaria)}

\section{ORDEM AMPHILINIDEA}

No presente estudo, foram encontrados exemplares de Schizochoerus liguloides Poche, 1922, no pirarucu, o tipo e único hospedeiro da espécie. Estes vermes são cestóides primitivos e sem segmentação, que vivem na cavidade peritoneal ou na bexiga natatória do hospedeiro. Foram vistos espécimes entre 5 e $13 \mathrm{~cm}$. de comprimento. Apesar do grande tamanho destes helmintos, não foi vista nenhuma indicação de patogenicidade. No entanto, o fato de 


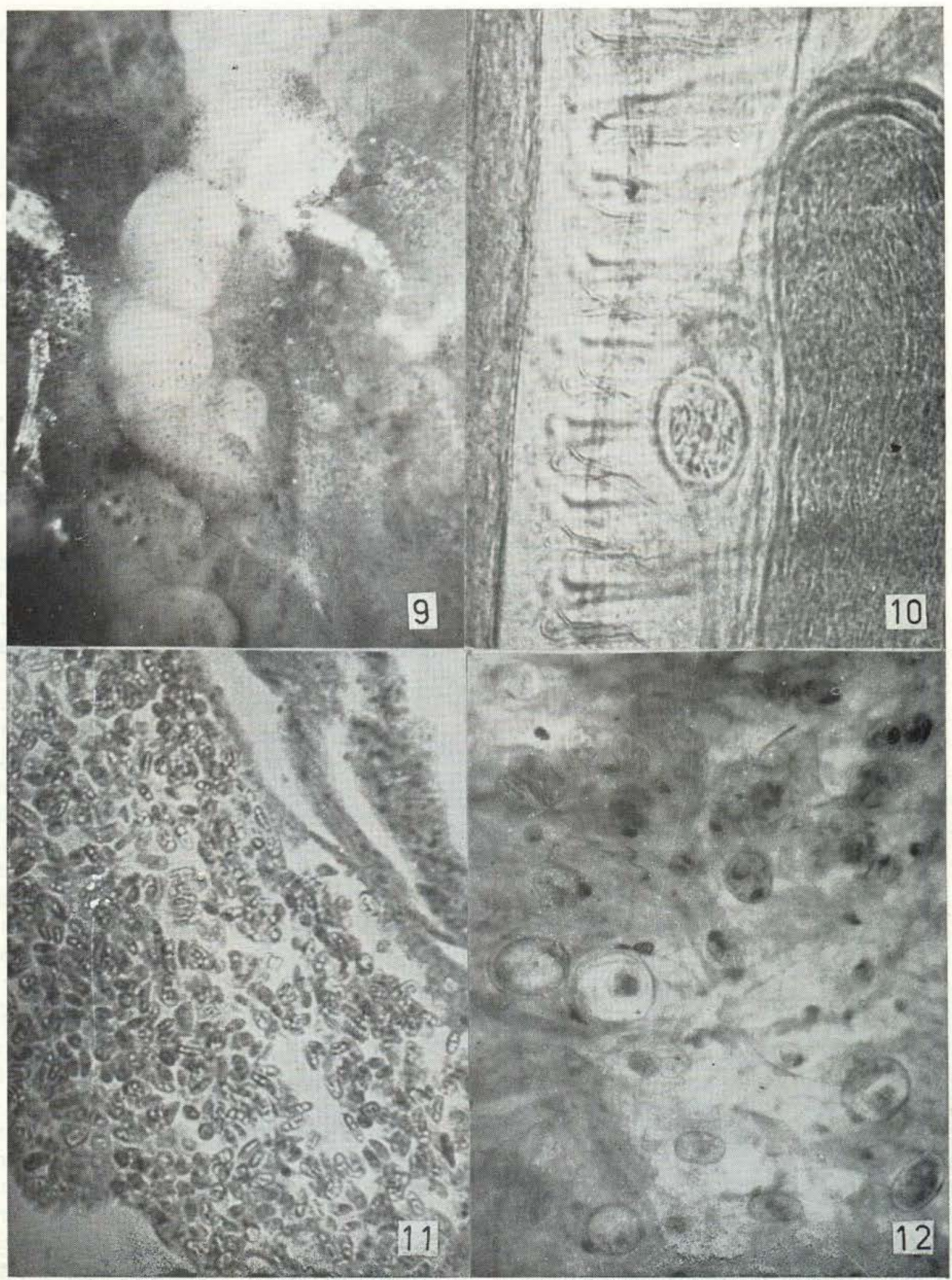

9 - Fungo no dorso de um tambaqui $(x$ 6); 10 - Cistos de Henneguya sp. dentro da lamela da brânquia da pescada ( $x$ 30); 11 - Cisto contendo esporos de Myxobolus do fígado do tambaqui ( $x$ 400); 12 - Plerocercóides (Proteocephalidae) encistados na parede do intestino do acará-açu ( $x$ 10). 
habitar o interior do peixe e ter a capacidade de penetrar nos tecidos, faz com que estes parasitas sejam considerados potencialmente patogênicos.

CLASSE EUCESTODA (= Cestoda)

\section{ORDEM PROTEOCEPHALIDEA}

A maioria dos cestóides de peixes de água doce e todos aqueles vistos no presente estudo, pertencem a esta Ordem. Os proteocefalídeos dos peixes amazônicos são conhecidos principalmente pelos trabalhos de Woodland (1934a, b, c; 1935a, b). A patogenicidade de cestóides nos peixes foi resumida por Freeman (1964) quem mencionou que um peixe pode toierar uma infecção maciça destes verm€s no intestino sem mostrar sintomas, mas o mesmo autor, citando uma comunicação particular de Margolis, afirmou que cestóides podem impedir o crescimento de salmões jovens. Ele também indicou que as invasões dos tecidos de peixes pelas larvas de Cestoda podem causar problemas graves e até a morte.

No presente estudo, foram encontrados larvas (pierocercóides) e adultos da Família Proteocephalidae em vários peixes amazônicos. Pretende-se publicar um estudo mais detalhado sobre este grupo no futuro. O exemplo mais notável da patogenia provocada pelas plerocercóides foi no caso de um acará-açu. Este peixe mostrou hemorragia extensiva no intestino e numerosos plerocercóides dentro da parece do mesmo órgão. As larvas estavam em vários estágios de crescimento e mostravam diferentes graus de encapsulação (Foto 12). Aparentemente, o peixe estava exposto a invasões repetidas ou contínuas na natureza. Além de causar um enfraquecimento do peixe por perdas de sangue, a presença de um número tão grande de cistos deve limitar a capacidade de absorção do intestino.

\section{FILO ACANTHOCEPHALA}

Os acantócéfalos são vermes com uma probóscide, ou tromba, invaginável e provida de ganchos ou espinhos. Os adultos utilizam a probóscide para fixar-se na parede do intestino do hospedeiro. Estes vermes são considerados patogênicos em virtude do dano causado ao epitélio intestinal e peio fato de a probóscide ocasionalmente furar a parede, resultando numa peritonite. Parece existir uma relação entre o tamanho e a forma da probóscide e a patogenidade.

No presente estudo, foram encontrados numerosos adultos de Neoechinorhynchus sp. nos tambaquis. Num grupo de 5 tambaquis jovens, de aproximadamente $38 \mathrm{~cm}$. de comprimento, foram encontrados intensidades de 112 , $173,354,358$ e 518 indivíduos. O grande número de vermes, que mediam até $3 \mathrm{~cm}$. de comprimento, pareciam causar uma oclusão parcial do trato digestivo. Já que este gênero de acantocéfalos tem uma probóscide pequena, não provocaram nenhuma reação inflamatória visível no epitélio do intestıno, mas é possivel que tenham interferido na capacidade de absorção do mesmo.

Foi encontrada no pirarucu uma outra espécie, de uma patogenicidade maior, identificada como Polyacanthorhynchus rhopalorhynchus (Diesing, 1851). Este verme é grande e tem uma probóscide comprida, provida de muitos ganchos. No presente estudo, foram examinados 3 pirarucus e todos estavam infectados, com 5,8 e 30 individuos, respectivamente. O espécime maior da coleção mediu $43 \mathrm{~cm}$. de comprimento. Esta espécie foi citada anteriormente do mesmo hospedeiro do Amazonas por Machado Filho (1947). Segundo ele, os vermes atingem $70 \mathrm{~cm}$. de comprimento, estando assim entre os maiores acantocéfalos do mundo. O mesmo autor notou a presença de aproximadamente 1.500 ganchos na probóscide e mais 180 espinhos na parte anterior do corpo.

Com uma probóscide tão comprida e armada, estes helmintos podem prender-se firmemente na parede do intestino, conseguir furar o epitélio e a submucosa e penetrar até as capas musculosas. Esta penetração provoca reações inflamatórios por parte do peixe e podem notar-se infiltrações celulares e hemorragias nos sítios de fixação. Segundo Bertocchi \& Francalanci (1963, citado em Williams, 1967), um acantocéfalo pertencente à mesma Superfamília Echinorhynchoidea (Echinorhynchus truttae) provocou a mortalidade de $80 \%$ nas trutas de um centro de piscicultura na Itália. 


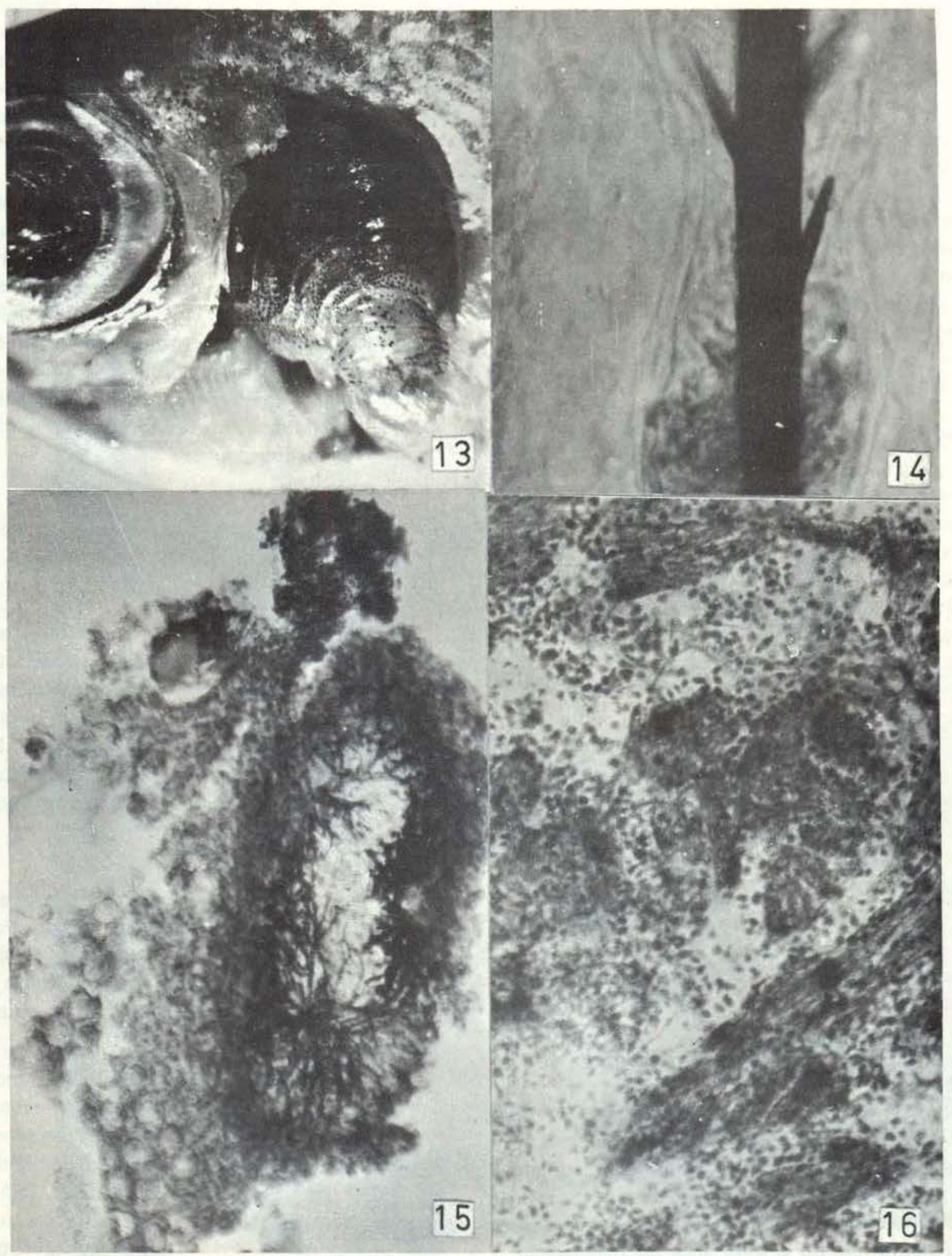

13 - Isópodo (Cymothoidae) atacando as brânquias de um caracóide de $5,5 \mathrm{~cm}$ de comprimento ( $\mathrm{x}$ 10); 14 - Espinho de planta sendo encistado na parede do intestino do acará-açu (x 400); 15 - Corte de um fungo da pele do tambaquí, mostrando infiltração de linfócitos (x 200); 16 - Adipose entre os músculos do coraçäo do pirarucu $(x 200)$. 
Outra espécie, com poucas indicações de patogenicidade, foi encontrada nos bodós e descrita com o nome de Gorytocephalus elongorchis por Thatcher (1979a). Até 10 indivíduos desta espécie foram vistos no bodó, Plecostomus sp. Esta espécie tem uma probóscide ainda menor que a de Neoechinorhynchus, e pertence à mesma Família, Neoechinorhynchidae. Já que o intestino do bodó é longo e delicado, com uma movimentação pouco rápida, os vermes não precisam de um órgão de fixação muito forte. Mesmo assim, os helmintos poderiam causar oclusões quando presentes em números suficientes.

\section{FILO NEMATODA}

Os nematódeos aduitos podem causar doenças ou a morte dos peixes e as larvas podem aparecer em tão grande número nos músculos a ponto de dificultar a venda ao consumidor. Um caso notável de mortandade de peixes provocada por nematódeos foi citado por Teixeira de Freitas \& Lent (1946). Eles notaram a presença do Ascaroidea Goezia spinulosa (Die. sing. 1839) em alevinos e larvas do acará-açu e do pirarucu procedentes do Posto de Piscicultura, do Estado de Ceará, Brasil. Aparentemente, a presença deste parasita impediu o cultivo destas espécies de peixes. Temos encontrado a mesma espécie de Goezia no acaráaçu, o que, sem dúvida alguma, poderia causar a mesma classe de problemas em qualquer tentativa de piscicultura na Amazônia.

Mais um grupo de nematódeos patogênicos são os Camallanoidea, sendo os gêneros mais comuns o Camallanus, Procamallanus e Spirocamallanus (Fotos. 3 \& 4.). Estes vermes têm uma cápsula bucal quitinizada e sempre aberta e podem sugar sangue em virtude de ter um esôfago poderoso. Neste estudo foi encontrado uma alta incidência $190 \%$ de Spirocamallanus sp. em pequenos matrinchãs (5 $11 \mathrm{~cm}$. de comprimento), capturados na natureza. Cada helminto estava agarrado ao epitélio do intestino e, quando retirado, deixava um pequeno ferimento e uma área de inflamação. Além dos danos físicos e a perda de sangue, os vermes podem ocasionar uma oclusão parcial do trato digestivo, o que provavelmente retardaria o crescimento dos peixes.
As larvas de nematódeos, encistadas em vários órgãos, foram vistas com freqüência. neste estudo. A Foto 8 mostra larvas de vários tamanhos no mesentério de um surubim. As larvas de nematódeos são difíceis de identificar, mas muitas daquelas que ocorrem nos te. cidos de peixes pertencem aos gêneros Contracaecum e Porocaecum (Ascaroidea). Os adultos destes gêneros geralmente parasitam as aves piscívoras. A patogenicidade dos nematódeos larvais depende muito do tamanho do peixe e órgão penetrado. Peixes adultos parecem ser capazes de tolerar grande número de larvas nos tecidos. Para o piscicultor e o pescador, o maior problema relacionado com estas larvas é que, quando são numerosas nos músculos dos peixes, ficam visíveis e dificultam a venda dos peixes.

\section{FILO ARTHROPODA}

\section{CLASSE CRUSTÁCEA}

Entre os crustáceos que parasitam peixes. reconhecem-se os seguintes grupos principais: copépodos, branquiúros e isópodos. Todos são, até certo ponto, patogênicos e a patologia está bem resumida no livro de Kabata (1970). Estes parasitas são entre as pragas mais importantes e as mais difíceis de controlar na prática da piscicultura. Este aspecto ainda não foi estudado na Amazônia.

Durante o presente estudo, foram observadas várias espécies de Argulus e de Dolops (Branchiura); Ergasilus e Lernaeidae (Copepoda); e várias espécies de Braga e Telotha (Isopoda, Cymothoidae) atacando peixes amazôni$\cos$.

Estes parasitas ainda estão sendo estudados, e se pretende publicar estas observações em detalhes no futuro. A Foto 13 mostra um membro de um casal de isópodos comendo as brânquias de um pequeno caracóide $(5,5 \mathrm{~cm}$. de comprimento). Neste caso, a destruição das brânquias foi evidente, e inevitávelmente deveria resultar na morte do peixe. A Foto 18 mostra uma espécie diferente de isópodo (medindo $2,5 \mathrm{~cm}$. de comprimento) que foi tirado da cavidade branquial de um tucunaré. 


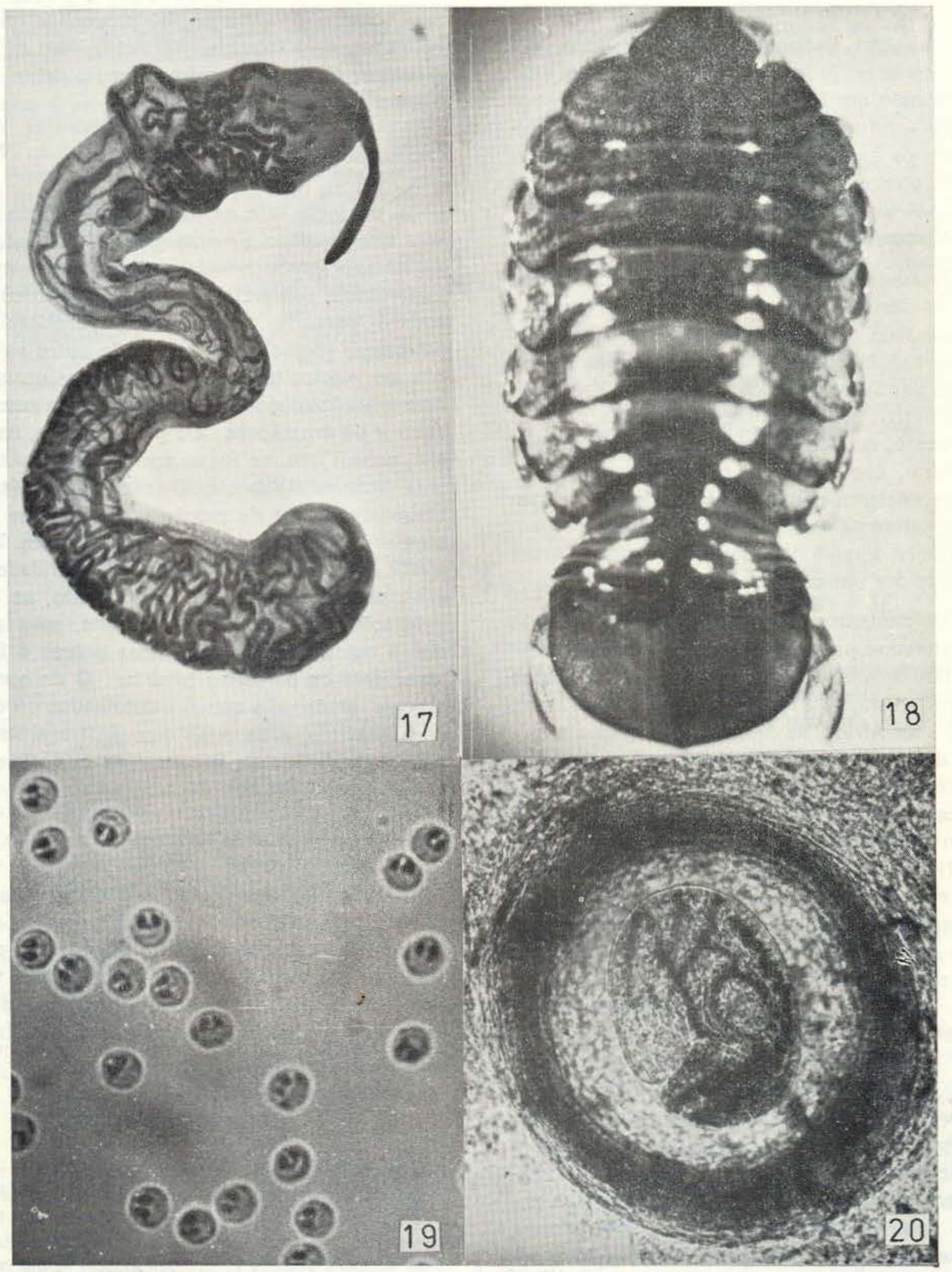

17 - Trematódeo (Brasicystis bennetti Thatcher, 1979) de um cisto subcutâneo no opérculo da pescada (x 20); 18 Isópodo (Cymothoidae) da boca do tucunaré (x 5); 19 - Esporos de Myxobolus sp. da nadadeira de um matrinchä ( $x$ 600); 20 - Cisto de uma metacercária (Acanthostomidae) da nadadeira do matrinchã ( $x$ 500). 


\section{SUBFILO PENTASTOMIDA}

A posição sistemática deste pequeno grupo de parasitas já foi muito discutida. Tem sido considerado um Filo independente, ou membro do Filo Arthropoda, relacionado com os ácaros ou com os branquiúros. Por enquanto, concordamos com a Idéia de colocar o grupo dentro do Filo Arthropoda, apesar de as relações ficaram obscuras.

Os adultos destes parasitas são parecidos com os vermes, mas têm um par de ganchos de cada lado da boca, na extremidade anterior. Vivem nas cavidades respiratórias dos vertebrados carnívoros. Os ovos saem do hospedeiro definitivo com as secreções nasais ou com as fezes $e$, quando ingerido por um vertebrado herbívoro, dão origem a uma larva de quatro pernas. A larva penetra nos tecidos do hospedeiro intermediário para transformar-se em uma ninfa, a qual fica ali encistada até serem comidas por um carnívoro.

Os pentastomídeos não são geralmente considerados parasitas de peixes. Foram citadas larvas e ninfas em peixes só na África Central (Fain, 1961, em Reichenbach-Klinke, 1973). Na África, as ninfas pertencem a espécies de pentastomídeos que amadurecem nos crocodilianos. No presente estudo, larvas, embriões e ninfas (até $5 \mathrm{~mm}$. de comprimento) foram encontrados nos mesentérios do surubim (Fotos. 7 \& 8.). Não foi possível identificar este material ainda, mas o jacaré poderia ser o hospedeiro definitivo. O papel dos pentastomídeos como parasitas dos peixes amazônicos está sendo estudado.

\section{PROBLEMAS METABÓLICOS}

O peixe, como qualquer outro animal, pode sofrer deficiências nutricionais e aberrações metabólicas. O fato de um peixe estar comendo e crescendo não implica que a taxa de crescimento esteja no máximo. Aliás, um peixe poderia estar aumentando seu peso só na forma de gordura, o que é de pouco valor comercial.

Um caso de adipose entre os músculos do coração foi visto num pirarucu grande, que tinha sido mantido em cativeiro por mais de um ano (Foto. 16.). Como o peixe era grande e foi mantido dentro de um aquário pequeno, a degeneração do coração foi provocada, possivelmente, pela falta de exercício. Sem dúvida, a adipose do coração enfraqueceu o peixe contribuindo para a sua morte.

\section{Conclusões}

É evidente que os peixes amazônicos têm uma alta incidência e uma grande variedade de parasitas. Temos notado nos peixes de maior importância comercial (tambaqui, pirarucu, tucunaré, pescada, surubim etc.) parasitas que em outras regic̃es e países estão entre as pragas da piscicultura. Entre eles, destacam-se: os mixuesporídeos, os monogênios, os nematódeos e os crustáceos. Os piscicultores, às vezes, acham que, se fosse possível controlar de uma maneira rígida a qualidade da água (especialmente a taxa de oxigênio e o $\mathrm{pH}$ ), os problemas com os parasitas desapareceriam. Tudo indica o contrário. Controle da qualidade da água poderia limitar, até certo ponto, as concentrações de bactérias e fungos, mas água que é quimicamente ótima para peixes é favorável para os parasitas também. O de que se precisa, então, são estudos detalhados do ciclo dos parasitas, e as suas vias de transmissão, com a finalidade de prevenir as infecções de peixes.

\section{AgRAdECIMENTOS}

Ficc muito agradecido à Biol. Angela B. Varella pela colaboração técnica prestada e ao Prof. Dr. J. A. Nunes de Mello por ter lido criticamente o texto deste trabalho. Agradeço também aos seguintes biólogos pela coleta de material: Dr. Jaques Gery, Sérgio P. Annibal e Miriam L. Carvalho.

\section{SUMmary}

General aspects of Amazonian fish pathology were discussed, and some of the governing principles were presented, such as: a) Amazonian fishes are little exposed to industrial polution, but sometimes die in large numbers because of reduced oxygen in the water brought on by a combination of a rapidly lowered ambient temperature and the decomposition of vegetable matter. b) The fish most likely to die are those with gill infections. c) Little overt pathology is to be expected in wild-caught fishes since sick fish are soon 
eliminated by predators, \& d) Pathology can be studied by surveying wild fish for parasites, and other pathogens, and then observing the effects of these agents on captive fish. The defense mechanisms used by Amazonian fish against: 1) foreign bodies, 2) fungi, 3) myxosporidians, 4) monogeneoidea, 5) trematodes, 6) cestodarians, 7) cestodes, 8) acanthocephalans 9) nematodes, 10) crustaceans and 11) pentastomids were discussed. Amazonian examples of these pathogens were reported, as were "black-spot disease" and three kinds os "yellow-spot disease". The ascaroid nematode, Goezia spinulosa, which is known to be a hazard to pisciculture, was reported from Amazonia. The "eye-fluke" Diplostomum, which can be pathogenic to fish and fatal to man, was reported from two host species. A case of fatty degeneration of the heart was reported in a large pirarucu, Arapaima gigas, that had been confined to a relatively small aquarium for over a year. It was suggested that insufficient exercise caused this anomaly.

\section{REFERÊNCIAS BIBLIOGRÁFICAS}

Ashton, N.; Brown, N.; EASTY, D.

1969 - Trematode cataract in freshwater fish. Jour. Small Animal Pract., 10: 471-478.

DIESING, K.M.

1850 - Systema Helminthum. v. 1. 679 p.

FREEMAN, R.S.

1964 - Flatworm problems in fish. Canadian Fish Cult., 32: 11-18.

Freeman, R.S.; Stuart, P.F.; CULlen, J.B.; RITChIE, A.C.: Mildon, A.; Fernandes, B.J.; Bonin, R.

1976 - Fatal human infection with mesocercariae of the trematode Alaria americana. Am. Jour. Trop. Med. Hyg., 25: 803-807.

HoFfMAN, G.L.

1967 - Parasites of North American Freshwater Fishes. U. Calif. Press. Berkeley. 486 p.

HOWELL, M.J.

1973 - The resistance of cysts of Stictodoza lari (Trematoda: Heterophyidae) to encapsulation by cells of the fish host. Internat. Jour. Parasit., 3: 653-659.

KABATA, Z.

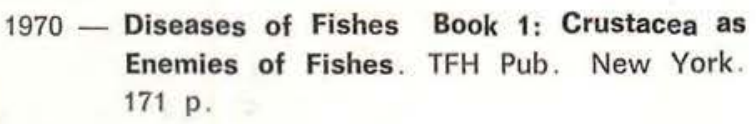
Enemies of Fishes. TFH Pub. New York. $171 \mathrm{p}$.

KRITSKY, D.C. \& THATCHER, V.E.

1974 - Monogenetic trematodes (Monopisthocotylea: Dactylogyridae) from freshwater fishes of Colombia, South America. J. Helm., 48: 59-66
1976 - New monogenetic trematodes from freshwater fishes of Western Colombia with the proposal of Anacanthoroides gen. n. (Dactylogyridae). Proc. Helm. Soc. Wash., 43: 129-134.

1977 - Phanerothecium gen. n and Fundulotrema gen. n., two new genera of viviparous Monogenoidea (Gyrodactylidae) with a description of $\mathbf{P}$. caballeroi $\mathrm{sp}$. $\mathrm{n}$, and a key to the Subfamilies and genera of the Family. Exerta Parasitolćgica en Memoria del Dr. Eduardo Caballero y Caballero. Univ. Nac. Auton. México. p. 53-60,

KRITSKy, D.C.; THATCher, V.E.; KAYTON, R.J.

1979a- Neotropical Monogenoidea. 2. The anacanthorinae Price, 1967, with the proposal of four new species of Anacanthorus Mizelle \& Price, 1965, from Amazonian fishes. Acta Amazonica, 9 (2): 355-361.

1979b- Neotropical Monogenoidea. 3. Five new species from South America with the proposal of Tereancistrum gen. $\mathrm{n}$. and Trinibaculum gen. $n$. (Dactylogyridae: Ancyrocephalinae). Acta Amazonica, 10 (2): 411-417.

Machado Filho, D.A.

1947 - Revisão do gênero "Polyacanthorhynchus" Travassos, 1920 (Acanthocephala, Rhadinorhynchidae). Rev. Brasil. Biol. 7: 195-201.

McCraren, J.P.; Landolt, M.L.; Hoffman, G.L.; MEYER, F.P.

1975 - Variations in response of channel catfish to Henneguya sp infections. (Protozoa: Myxosporidea). J. Wildl, Dis, 11: 2-7.

PrICE, C.E.

1967 - The freshwater monogenetic trematodes of South America, Riv. Parassit. 28: 87-95.

REICHENBACH-KLINKE, H.H.

1973 - Fish Pathology. (tradução do livro publicado em Alemão em 1965). TFH Pub. New York. 512 p.

STEMPNIEWSKI, H.L.

1970 - Doenças parasitárias dos peixes - gene ralidades. (em Poluição e Piscicultura) Com. Interestad. Bacia Paraná-Uruguai. Fac. Saúde Púb. USP. p. 155-162.

SUYDAM, E.L.

1971 - The micro-ecology of three species of monogenetic trematodes of fishes from the Beaufort-Cape Hatteras area. Proc. Helm. Soc Wash 38: 240-246. 
TEIXeira de Freitas, J.F, \& Lent, H.

1946 - Infestação de apaiarís "Astronotus ocellatus" (Agassiz) pelo nematódeo "Goezia spinulosa" (Diesing, 1839). Rev. Brasil. Biol. 6: 215-222.

THATCHER, V.E.

1978 - Quatro espécies novas da família Haploporidae (Trematoda: Digenea) de peixes de água doce da Colômbia, com uma revisão do gênero Saccocoelioides Szidat, 1954. Acta Amazonica, 8 (3): 477-484.

1979a - Uma nova espécie de Gorytocephalus Nickol e Thatcher, 1971, (Acanthocephala: Neoechinorhynchidae) do acari-bodó (Pices: Loricariidae) da Amazônia, Brasil. Acta Amazonica, 9 (1): 199-202.

1979b- Brasicystis bennetti n. gen., n. sp. (Trematoda: Didymozoidae) parasita da pescada (Sciaenidae) da Amazônia, Brasil. Acta Amazonica, 9 (4): 747-749.

Travassos, L.; Teixeira de Freitas, J.F.; Kohn, A.

1969 - Trematódeos do Brasil. Mem. Inst. Oswaldo Cruz. 67: 1-886.

WILLIAMS, H.H.

1967 - Helminth diseases of fish Helm Abst. 36: 261-287.
WOODLAND, W.N.F.

1934a - On six new cestodes from Amazon fishes Proc. Zool. Soc. London. pt. 1: 33-46.

1934b- On the Amphilaphorchidinae, a new Subfamily of proteocephalid cestodes, and Myzophorus admonticellia, gen. et $\mathrm{sp}$. n., parasitic in Pirinampus spp from the Amazon. Parasit. 26: 141-149.

1934c- On some remarkable new cestodes from the Amazon siluroid fish, Brachyplatystoma filamentosum (Lichtenstein). Parasit. 26: 268-277.

1935a - Some more remarkable cestodes from Amazon siluroid fish. Parasit. 27: 208-225.

$1935 \mathrm{~b}$ - Some new proteocephaliós and a ptychobothriid (Cestoda) from the Amazon. Proc. Zool. Soc. London. pt. 3: 619-624

YAMAGUTI, S.

1971 - Synopsis of Digenetic Trematodes of Vertebrates. Keigaku Pub. Co., Tokyo. 1772 p

(Aceito para publicação em 02/01/80) 